\title{
Active Hydrothermal Features \\ as Tourist Attractions
}

\author{
Patricia Erfurt-Cooper
}

\begin{abstract}
Tourists are looking increasingly for adventurous experiences by exploring unusual and interesting landscapes. Active volcanic and hydrothermal landscapes and their remarkable manifestations of geysers, fumaroles and boiling mud ponds are some of the surface features that fascinate visitors of National Parks, Geoparks and World Heritage areas worldwide. The uniqueness of hydrothermal activity based on volcanism has provided popular tourist attractions in many countries for several thousand years. The Romans for example have used hydrothermal springs on the Italian island Ischia and visited the Campi Flegrei for recreational purposes. In Iceland the original Geysir already attracted international visitors over 150 years ago, who came to observe this spectacular hydrothermal phenomenon. In Greece and Turkey volcanic hot springs have historically provided attractive destinations, as well as in New Zealand, Japan and the Americas. The fact that locations with hydrothermal activity based on active volcanism have acquired various forms of protected site status, adds a further dimension to their attraction and demonstrates a significant contribution to sustainable and nature based tourism. Countries such as Iceland, New Zealand and Japan have a long tradition of using hydrothermal activity in its various forms to offer tourists a unique natural experience. These environments however are also known for their unpredictable and potentially hostile nature, as the use of hydrothermal features as a natural resource for tourism does harbour certain risks with the potential to affect human health and safety. Hydrothermal systems have erupted in the past, thereby causing the destruction of their immediate environment. Depending on the level of magnitude explosions of super heated water and steam mixed with fractured rocks and hot mud can be violent enough to create craters varying in size from a few metres
\end{abstract}

P. Erfurt-Cooper $(\square)$

GEOTOURISM Australia, Canberra ACT, Australia

e-mail: Patricia.Erfurt@my.jcu.edu.au 
to several hundred metres in diameter. Apart from unexpected eruptions of hydrothermal vents with the potential to cause thermal burns, further risk factors include seismic activity such as earthquakes, lethal gas emissions of hydrogen sulphide $(\mathrm{H} 2 \mathrm{~S})$ as well as ground instability through hydrothermal alteration. While it is essential to prevent injuries to tourists the management of hydrothermal hazards remains problematic. Precursory signs are not well understood by the general public and the communication of imminent danger is frequently unachievable. As a consequence serious thought needs to be given to the risk factors and the potential danger of areas in the proximity of active hydrothermal manifestations such as extreme hot springs and geysers. To improve the safety standards in hydrothermal landscapes that are used as main features in tourism, strategic guidelines for best practice management must cover ALL active volcanic and hydrothermal areas. This chapter looks at management issues at hydrothermal destinations with special consideration of areas where these unique features are integrated as tourist attractions. Examples from destinations traditionally based on active volcanic and hydrothermal phenomena are presented as case studies to highlight the risk management processes in individual countries. Potential hazards in volcanic and hydrothermal areas are assessed with a focus on the prevention of accidents and injuries to tourists.

\section{Keywords}

Hydrothermal activity - Protected site status - Risk management • Sustainable tourism - Volcanic environments

\section{Introduction}

\subsection{Visitor Safety in Hydrothermal Environments}

Tourists are looking increasingly for adventurous experiences by exploring unusual and interesting destinations. Active volcanic and hydrothermal landforms and their remarkable manifestations of geysers, fumaroles and boiling mud ponds are some of the surface features that fascinate tourists worldwide. The uniqueness of hydrothermal activity based on volcanism has provided popular tourist attractions in many countries for several thousand years. The Romans for example used hydrothermal springs on the Italian island Ischia and visited Campi Flegrei for recreational purposes. In Iceland the original Geysir attracted international visitors over 150 years ago who came to observe this spectacular hydrothermal phenomenon. In many other countries worldwide (Greece, Turkey, New Zealand, Japan, China and the Americas) hydrothermal activity in its various forms has historically provided attractive destinations.

The fact that locations with hydrothermal activity, commonly based on active volcanism, have acquired various forms of protected site status (e.g. National Parks, Geoparks and World Heritage Areas) adds a further dimension to their attraction and demonstrates a significant contribution to sustainable and nature based tourism. However, these environments are also known for their unpredictable and potentially hostile nature and the use of hydrothermal features as a natural resource for tourism does have certain risks with the potential to affect human health and safety. 
This chapter examines the communication of hazards and the potential risks associated with sites where hydrothermal features are major tourist attractions. Examples from tourist destinations based on active hydrothermal phenomena are presented as brief case studies to highlight the importance of hazard and risk communication. To prevent unnecessary exposure to hazards, which can escalate into a crisis situation, visitors of hydrothermal attractions must be made aware of potential hazards that could carry the risk of personal injury or death. As many hydrothermal areas are located in close proximity to active volcanic systems, this chapter occasionally refers to both environments and their correlated hazards.

\subsection{Definitions of Hazard, Risk and Vulnerability}

First of all, the actual meaning of the common language terms hazard, risk and vulnerability needs to be clarified in relation to the subject matter of this chapter. While the term hazard is often used as a synonym for danger and/or risk, a hazard is scientifically defined as the probability of a natural event occurring as well as being a potential source of vulnerability (exposure to danger). The term vulnerability refers to the susceptibility and inability of humans or physical structures to withstand the impacts of natural hazards. Vulnerability in hydrothermal areas based on volcanic activity takes into account the real possibility of causing injury, damage and loss of life (Aspinall and Blong 2015; Barclay et al. 2015; Jolly and De La Cruz 2015; McGuire et al. 2009; UNISIDR 2016). Vulnerability can be a consequence of either being unsuspecting of potential risks or ignoring these while visiting sometimes remote or unsafe areas without suitable defence structures or shelters. Taking a risk in these environments therefore can result in vulnerability due to exposure of hazards and includes the probability of being harmed in the process. This can be based on a lack of awareness about the potential risks and/or a lack of appropriate hazard communication.

Potential hazards in areas of hydrothermal activity (Table 7.1) are generally assessed with the main focus on minimising the risk of accidents and injuries. The process of risk identification recognises potential hazards as well as any potential vulnerability from the damaging effects of a hazard (Aspinall and Blong 2015; UNISDR 2014). Also, the risk to visitors is considered to increase with extended time spent in an active hydrothermal area (Bratton et al. 2013). It is therefore highly recommended that all visitors of active hydrothermal environments are aware of the particular hazards and the potential risks in these areas.

In this regard, a crisis can be defined as an unstable and hazardous situation of increased danger that has reached a critical phase (De La Cruz-Reyna et al. 2000). Communication of scientific advice in a crisis situation must clearly reflect the level of danger to raise awareness about the real hazard level and to avoid misunderstanding as to the likely consequences (Jolly and De La Cruz 2015).

Table 7.1 Examples of the most common hydrothermal hazards

Potential hazards in active hydrothermal areas

Seismic activity-unexpected

earthquakes

Toxic fumes and gas emissions

Unstable ground

Unexpected hydrothermal eruptions

Hydrothermal steam discharge

Sudden change of water temperature
Sudden change of location of hot water source

Sudden change of flow rates, direction and currents of hot water source

Thermal burns from extreme hot springs

Health hazards from thermophilic microbes and bacteria 


\subsection{Hydrothermal or Geothermal?}

Now and again there appears to be confusion between the terms hydrothermal and geothermal. The term hydrothermal refers to hot water and is derived from the Greek meaning of hydros for water and thermos for heat. Likewise, the term geothermal has its origin in the Greek language with the prefix geo referring to earth. To clarify the difference between hydrothermal and geothermal Heasler et al. (2009) describe hydrothermal as a subset of geothermal, whereby geothermal refers to any system that transfers heat from the interior of the earth to the surface involving water, both as a liquid and steam (Keary 1996). All hydrothermal systems related to volcanism are based on a geothermal heat source in the form of an active magma chamber or a cooling magma body (Hochstein and Browne 2000). Consequently, water emerging from a hydrothermal vent is correctly termed geothermal water, but this term can also refer to water heated by convective circulation deep underground without the proximity of a magma body (Heasler et al. 2009). The actual process of heat transfer involves the circulation of groundwater from a subterranean reservoir to the surface. Here, individual hydrothermal features emerge in the form of hot springs and geysers, or in the case of subaqueous hydrothermal vents in close proximity to an underlying magma body as the emission of superheated mineral rich solutions, known as Black or White Smokers.

The temperature range of such hydrothermal systems is estimated to be typically between $50{ }^{\circ} \mathrm{C}$ and up to over $400{ }^{\circ} \mathrm{C}$ in deeper reservoirs (Haase et al. 2009). According to Heasler et al. (2009) hydrothermal systems present a continuum of resource temperatures that is relatively openended. In comparison the temperature range of natural hot springs utilised for health and recreational facilities lies generally between $37{ }^{\circ} \mathrm{C}$ and the boiling point of water at sea level $\left(100{ }^{\circ} \mathrm{C}\right)$. These natural hot springs, independent of whether their origin is volcanic or non-volcanic, are frequently referred to as either geothermal or just as thermal springs (Erfurt-Cooper 2012).

\section{The Challenges of Hydrothermal Tourist Sites}

\subsection{Direct Use of Hot Springs as Tourist Attraction}

Hydrothermal features play an important role in tourism and are a favourite with people who are looking for unusual natural experiences with a touch of adventure (Tables 7.2 and 7.3). Many hydrothermal areas are marketed as family friendly must-see destinations, offering a once-ina-lifetime occasion to encounter the raw power of nature. Another reason for people to visit active areas is that features may be ephemeral and may become inaccessible or disappear altogether due to earthquakes or volcanic activity (e.g. Valley of the Geysers in Kamchatka-mudflow in 2007).

Hot springs, geysers, boiling lakes, bubbling mud pools and hissing steam vents are common in countries with active as well as dormant volcanism (e.g. New Zealand, Japan, Iceland (Case Study 7.1), the Americas, Africa and China). Located in protected areas such as national parks or geoparks can be an advantage in controlling access to hazardous sites, although providing safety is a definite challenge, which depends on many variables including language barriers. For example, the family affected in Case Study 7.2 did not speak English, which may have contributed to the horrific accident.
Table 7.2 Examples of hydrothermal features based on volcanism that are used as tourist attractions worldwide

\section{Hydrothermal Features used as Tourist Attractions}

\begin{tabular}{l|l}
\hline Fumaroles/steam vents & Boiling mud pots \\
Geysers & Explosion craters \\
Hot lakes & Sinter terraces \\
Hot rivers and streams & Hot springs (for bathing) \\
Hot waterfalls & Hot springs (for cooking) \\
Mud volcanoes & Geothermal power stations
\end{tabular}


Table 7.3 Hydrothermal features play an important role in the marketing of tourist destinations

The role of hydrothermal features in tourism

- Unique selling point for destination development

- Value adding when combined with other recreational facilities

- Significant resource for Geotourism with opportunities to learn about hydrothermal features and their geological heritage
- Integration into Health \& Wellness tourism by utilising geothermal spring water

- Sustainable development based on the use of renewable energy

- Economic benefits through the use of geothermal energy for local infrastructure

\section{Case Study 7.1: Iceland}

Volcanic and hydrothermal tourist attractions are an important part of the visitor experience in Iceland. The geysers at Haukadalur and the hot springs at Landmannalaugar and Hveragerði are commonly included in trip agendas. The Blue Lagoon, not far from the capital Reykjavik and the Mývatn Nature Baths in Iceland's north-east are unique bathing pools fed by excess geothermal water from the neighbouring power stations Svartsengi and Krafla. In fact, tourists can visit most of the Icelandic geothermal power plants and learn about the generation of clean renewable energy. "With more than 100,000 visitors a year, the geothermal power plants and related installations in Iceland are one of the top tourist destinations in Iceland" (Think Geoenergy 2015).

\section{Case Study 7.2: Rotorua-New Zealand}

While tens of thousands of people safely visit New Zealand's geothermal parks each year, tragic accidents can happen. In 2010 a ten-year old boy died after falling into one of Rotorua's hot water pools (NZ Herald 2013). According to eye witnesses the boy had burns from his head to his feet and was flown to a hospital in Auckland to be treated in intensive care, but later died (BBC News 2010). Following the accident, Rotorua District Council reviewed the park's safety and added 60 new warning signs as well as additional fencing. However, according to council officials, visitors are frustrated when there are too many fences, and climb over for a better view (TVNZ 2012). An inquest later found that the boy had climbed a wall and fell into one of the hot pools, suffering burns to almost $100 \%$ of his body.

Geothermal water is used worldwide as a renewable resource for generating energy, commercial, agricultural and industrial purposes, space heating, bathing and rehabilitation as well as for drinking and cooking. At Yellowstone (USA) Native Americans have historically used hydrothermal features for food preparation. Today geothermal cuisine is regularly used as a tourist attraction at many active volcanic and hydrothermal destinations. In New Zealand tourists can visit natural cooking pools such as Ngāraratuatara (Rotorua) and observe ancient Māori cooking techniques. In Iceland geothermal or "geyser cooking" is attractive to tourists, with a restaurant in Hveragerði specialised in geothermal cuisine using steam from volcanic activity. On the volcanic islands of the Azores one of the most remarkable tourist attractions of Furnas (San Miguel) is geothermal cooking, offering typical Azorean cuisine at many local restaurants. Hot spring cooking is equally popular in Japan with jigoku-mushi one of many sought after dishes prepared using geothermal steam. Apart from these well-known examples, many countries worldwide, including Kenya, the Philippines, Mexico and Indonesia, use geothermal water for cooking.

On account of their proximity to active volcanism, the management of tourist areas with underlying hydrothermal systems is therefore not an easy task. Given the potential hazards of 
active environments, both volcanic and hydrothermal, it is essential that sufficient warnings and safety guidelines are available and emergency procedures and crisis response resources have been prepared along with appropriate channels for effective communication.

\subsection{Potential Hazards-Beauty or Beast?}

Although hydrothermal areas are attractive to visitors, there are a number of inherent hazards and risks. Depending on the magnitude, explosions of super-heated water and steam mixed with fractured rocks and hot mud can be violent enough to create craters varying in size from a few metres to several hundred metres in diameter. Apart from the unexpected eruptions of hydrothermal vents with the potential to cause thermal burns, further risk factors include seismic activity such as earthquakes and lethal gas emissions, as well as ground instability through hydrothermal alteration.

Considering the number of hydrothermal hazards (Table 7.1) it becomes clear that there is indeed a possibility for accident and injury, despite the fact that fumaroles, geysers and bubbling mud pools present such a picturesque photo opportunity. Adding to the list of potential problems is the frequent underestimation of the safety risk from nearby active volcanoes, where circumstances can quickly change in case of unexpected eruptions. Failing to seek information about current activity levels prior to visiting such areas, or not following warnings, can lead to serious injuries or death as many people are not aware of the various hazards they may encounter in these environments.

While life-threatening hydrothermal eruptions are relatively rare, toxic fumes and gas emissions are rather common in active areas. These naturally occurring gases are emitted from volcanic craters and fumaroles or diffused through the soil (Hansell et al. 2006). Toxic gas emissions can also occur in the absence of eruptive activity. Some of the most common gases include
Hydrogen Sulphide $\left(\mathrm{H}_{2} \mathrm{~S}\right)$, Carbon Dioxide $\left(\mathrm{CO}_{2}\right)$ and Sulphur Dioxide $\left(\mathrm{SO}_{2}\right)$. All of these are dangerous to human health with $\mathrm{H}_{2} \mathrm{~S}$ causing instant death at extreme levels (Case Study 7.3).

\section{Case Study 7.3: Akita, Japan}

In December 2005 a family of four tragically died near a hot spring resort from hydrogen sulphide poisoning. While playing two young boys tried to retrieve their Frisbee from a snow covered hollow, unaware that the depression in the ground contained a lethal concentration of $\mathrm{H}_{2} \mathrm{~S}$. When both children suddenly collapsed their mother tried to save them, but also died instantly after inhaling the toxic gas. When searching for his family the father discovered them lying on the ground and also entered the hollow. He initially survived, but passed away a day later in hospital (Japan Times 2005).

Being denser than air $\mathrm{H}_{2} \mathrm{~S}$ can accumulate in low lying areas such as hollows and depressions in the landscape and remain trapped if not dispersed by wind (USGS ${ }^{1}$ 2014, Whittlesey 2014; Williams-Jones and Rymer 2000). Although $\mathrm{H}_{2} \mathrm{~S}$ at low levels has a distinctive odour often described as rotten egg smell, at higher concentrations this gas cannot be detected through smell which means there is no warning.

In Hawai'i tourists regularly visit the Hawai' $i$ Volcanoes National Park to observe the glowing lava flows. A special attraction is the area where the lava flows enter the ocean, instantly boiling the seawater and turning it into vapour (Hansell et al. 2006; Heggie et al. 2010; Williams-Jones and Rymer 2000). This chemical interaction between molten lava and sea water creates a white plume known as lava haze or $L A Z E$ and is frequently mistaken for a 'harmless' steam cloud. This plume however contains a mixture of hydrochloric acid $(\mathrm{HCl})$ and concentrated seawater with up to 2.3 times average salinity and 
with $\mathrm{pH}$ levels as low as 1.5-2.0 (Heggie et al. 2010; USGS $^{1}$ 2014). As a precaution the USGS information website (USGS ${ }^{2}$ 2014) clearly advises people not to stand beneath the volcanic laze plume or downwind of it because hydrochloric acid is toxic and can cause irritation of the throat, lungs, eyes, and nose. In fact, volcanic laze is dangerous enough to kill (Case Study 7.4).

\section{Case Study 7.4: Clouds that can kill- Acidic LAZE plumes}

During November 2000 in the Hawai'i Volcanoes National Park two people were caught in a volcanic laze plume near the point where lava flows enter the ocean and died as a result of pulmonary oedema caused by inhalation of volcanic laze. Conditions near this point involved the threat of exposure to dense hydrochloric acid mist, which subsequently engulfed the victims in an extremely hot and acidic cloud. Nevertheless, the area can be accessed without restrictions, although warning signs and safety instructions should never be ignored (Heggie et al. 2010).

Hydrothermal areas for example in Japan, New Zealand or at Yellowstone warn visitors about the risk of encountering unstable ground, as hydrothermal features may only be covered by a thin crust that easily breaks underfoot, and may cause thermal burns (Case Study 7.5; Fig. 7.1).
Unexpected hydrothermal eruptions can become a serious danger also, causing impact injuries and burns from scalding steam emissions, hot mud and ejected rocks. Hydrothermal steam discharge from fumarolic vents can suddenly increase without warning, or steam plumes can change their direction with the wind, which can result in thermal burns as well as respiratory problems. Likewise, a sudden change in the water temperature of hot streams, rivers and lakes, where geothermal spring water mixes with cooler water, can result in serious injuries if people take a soak in what they initially perceive as warm water.

\section{Case Study 7.5: New Zealand- Geothermal Wonderlands}

New Zealand's hydrothermal sites provide walkways for tourists in potentially hazardous areas. Boiling lakes, geysers, mud pools, and especially areas of unstable ground are fenced off to reduce the risk for accidents and injury due to underlying geothermal activity. This practice protects both the tourists and the mineral deposits which are part of the attraction of hot springs (Roscoe 2010). However, there is still a need for multilingual warning signs at hydrothermal destinations to increase awareness about potential hazards and visitor safety.
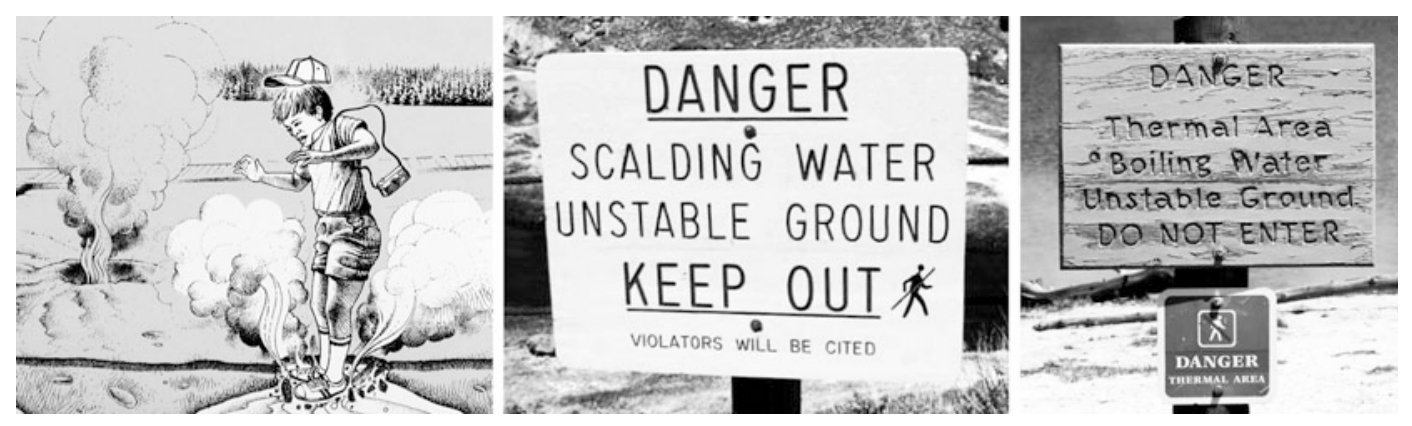

Fig. 7.1 Examples of warning signs at popular North American hydrothermal tourist destinations. The use of pictures or symbols is effective and recommended if there is the lack of warnings in several languages (Compare Figs. 7.2, 7.3, and 7.4). Source Public Domain 


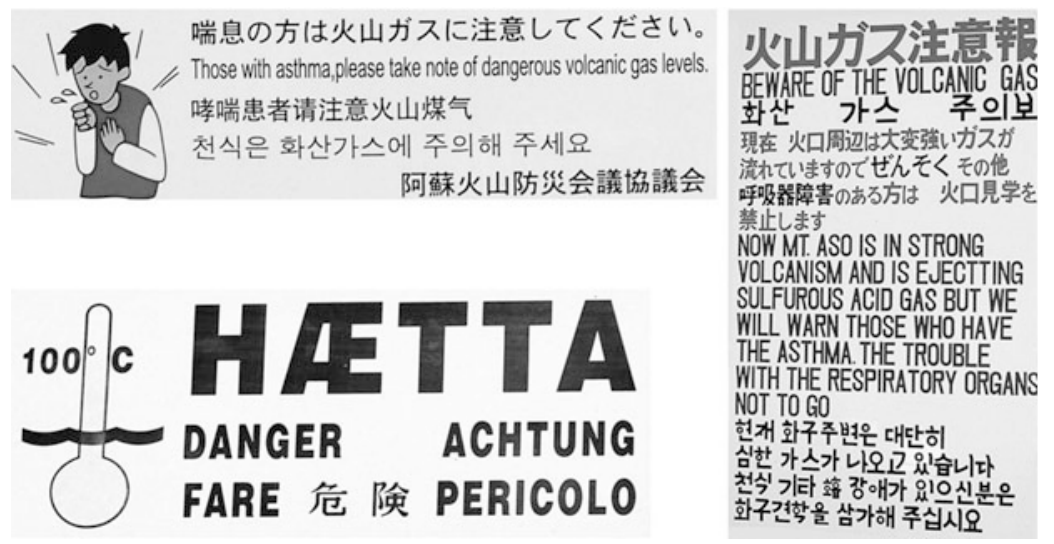

Fig. 7.2 Examples of warning signs in Japan and Iceland. The effort to communicate hazards to international visitors is obvious and commendable, while at the same time adding urgency to the warnings. Source Patricia Erfurt-Cooper

Other risks involve the unexpected change of location of the hot water source, especially if these are located below the surface of a stream of lake. The sudden change of flow rates, direction and currents of the hot water source is another hazard and a risk that people frequently underestimate. The temperature of hydrothermal features such as erupting geysers can also be underestimated from a distance, which can result in thermal burns on approach.

Another important health hazard involves disease-causing organisms such as thermophilic microbes and bacteria. Legionella bacteria and Naegleria fowleri have been identified at thermal pools used for recreation (Fig. 7.3) with some hydrothermal locations reportedly having problems with Primary Amoebic Meningoencephalitis (PAM), a rare but life-threatening infection caused by the organism Naegleria fowleri (Erfurt-Cooper and Cooper 2009). While casual exposure via the skin does not result in infection, the inhalation of contaminated water can cause serious problems, as the pathogenic amoebae migrate up the sinuses and surrounding tissue to the brain (Barnett et al. 1996). A common hot pool safety warning in New Zealand advises that "When swimming in natural hot pools, where the water comes out of the ground, keep your head above water because there is a small risk of contracting an illness called amoebic meningitis. While very rare, this illness is serious".
Public bathing facilities in the form of hot spring pools are often also accessible in hydrothermal areas. Bathing accidents are not unusual at natural hot springs, thermal health spas and geothermally heated communal pools. Being generally careless or consuming alcohol prior to using hot spring pools shows a lack of common sense and ignorance of safety advice, but is unfortunately all too common. In general, developed hot spring spas and pools advise visitors on the risk of excessive soaking in hot water when suffering from certain health conditions.

\section{Communicating, Forecasting and Managing Natural Hazards- A Mission Impossible?}

\subsection{The Main Challenges of Hazard Communication}

Hazard education and risk communication are an essential foundation for effective risk management (Leonard et al. 2008; Paton et al. 2001) with the aim to prevent harm through injury or death, while crisis communication focuses on informing the public during a crisis event (Leonard et al. 2008; Steelman and McCaffrey 2013; Williams and Olaniran 1998). To maximise the effectiveness of warnings, signage plays a critical role in increasing hazard awareness of the public 


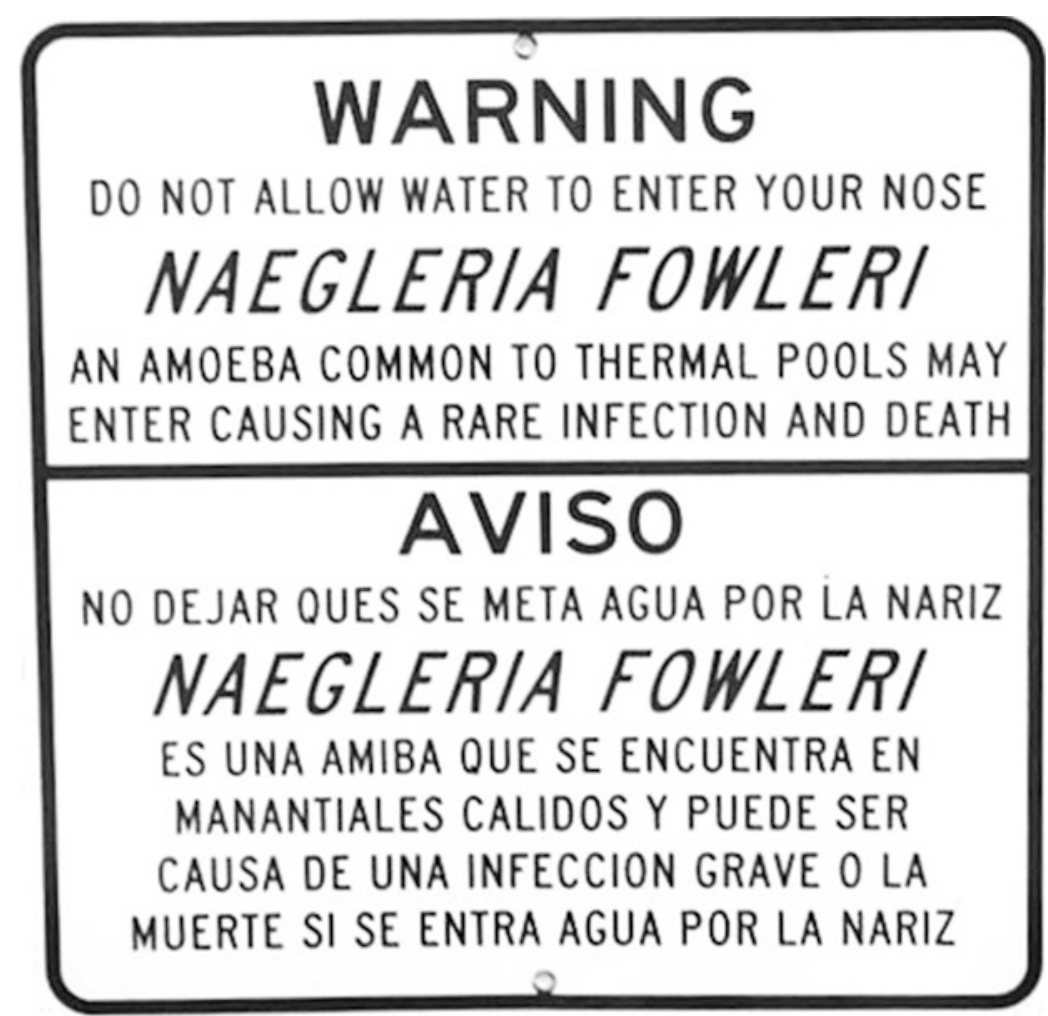

Fig. 7.3 Bilingual sign at a thermal pool warning visitors of the risk of contracting amoebic meningitis. Source Public Domain

(Dengler 2005; Leonard et al. 2008). Visitors of hydrothermal and volcanic environments may be aware of potential hazards, but once an emergency situation develops, reaching people in remote locations can be fraught with problems. Apart from the geophysical hazards, a number of additional challenges at hydrothermal tourist sites also have to be considered (Table 7.4).

While effective communication starts with essential warning signage in hazardous areas, warnings, safety instructions and hazard maps, if ignored, can result in the loss of lives. The reliance on smart phones and a potential lack of reception is a further challenge in achieving effective communication. Some of the biggest problems in hazard communication however are language barriers, with more signs displaying multilingual warnings and effective symbols or pictograms needed at many hydrothermal tourist destinations.
Another main difficulty is to keep a record about the exact numbers of people present in an affected area during a crisis situation. Uncertainty over the whereabouts of tourists (hikers, climbers etc.) can cause preventable fatalities if there is insufficient time to reach all affected people under deteriorating conditions. This is complicated by the fact that predictions and/or forecasts of hazardous activity can often only be made based on the frequency and the type of past hazardous activities of a particular area. To realistically forecast future activity and determine which area may be subject to potential threats is only possible if the site is constantly monitored and assessed. Scientists can advise on possible danger zones and create hazard maps in cooperation with local authorities to show unsafe and safe areas, escape routes and shelters, but this is at best only a probability assessment. 
Table 7.4 Challenging factors related to hazards in active hydrothermal environments

\begin{tabular}{|c|c|c|}
\hline \multicolumn{3}{|c|}{ Potential problems at hydrothermal tourist sites } \\
\hline \multicolumn{2}{|l|}{ Challenging factors } & Examples/Consequences \\
\hline Remote areas & $\begin{array}{l}\text { Uncertain visitor numbers } \\
\text { Uncertain access and escape routes } \\
\text { Rescue response delayed or impossible }\end{array}$ & Valley of Geysers, Kamchatka, Russia \\
\hline Large areas & $\begin{array}{l}\text { Monitoring visitors difficult } \\
\text { Emergencies can go unnoticed }\end{array}$ & Yellowstone, USA (Case Study 7.8) \\
\hline Large crowds & $\begin{array}{l}\text { Crowd control to avoid panic } \\
\text { Unknown and/or blocked escape routes }\end{array}$ & $\begin{array}{l}\text { Hydrothermal parks (New Zealand) (Case } \\
\text { Study 7.5, } 7.7 \text { and } 7.9 \text { ) } \\
\text { Yellowstone (USA) }\end{array}$ \\
\hline Confined spaces & $\begin{array}{l}\text { Blocked escape routes } \\
\text { Potential of panic causing injuries }\end{array}$ & $\begin{array}{l}\text { Small hydrothermal parks or Jigoku (Japan) } \\
\text { (Case Study 7.6) }\end{array}$ \\
\hline Communication barriers & $\begin{array}{l}\text { Insufficient warning signs } \\
\text { Lack of emergency information } \\
\text { Lack of mobile phone reception }\end{array}$ & $\begin{array}{l}\text { Areas with limited or no communication } \\
\text { infrastructure, remote areas }\end{array}$ \\
\hline Language barriers & $\begin{array}{l}\text { Signage does not communicate warnings } \\
\text { effectively }\end{array}$ & $\begin{array}{l}\text { Tourist sites only using signs in the local } \\
\text { language }\end{array}$ \\
\hline $\begin{array}{l}\text { Lack of shelters or difficult } \\
\text { access to shelters }\end{array}$ & \multicolumn{2}{|c|}{ Shelters not built strong enough to protect from eruption fallout or from toxic gas emissions } \\
\hline $\begin{array}{l}\text { Transport logistics in crisis } \\
\text { situations }\end{array}$ & \multicolumn{2}{|c|}{$\begin{array}{l}\text { Access for rescue and transport of injured people in remote locations } \\
\text { Treatment and medical care }\end{array}$} \\
\hline Time factor & \multicolumn{2}{|l|}{ Sudden onset of crisis } \\
\hline Political & $\begin{array}{l}\text { Access limited or prevented during times of } \\
\text { political instability } \\
\text { Cross-border disagreements }\end{array}$ & $\begin{array}{l}\text { Erta Ale and Dallol Hydrothermal Field } \\
\text { (Ethiopia) }\end{array}$ \\
\hline Financial & $\begin{array}{l}\text { Lack of funding to implement safety strategies } \\
\text { Economic mismanagement }\end{array}$ & $\begin{array}{l}\text { Affects emergency management, strategic } \\
\text { planning and rescue response }\end{array}$ \\
\hline Topography & Extreme terrain and physical surface features & $\begin{array}{l}\text { Area is difficult to negotiate due to } \\
\text { environmental factors }\end{array}$ \\
\hline Sudden weather changes & $\begin{array}{l}\text { Additional natural hazards such as strong wind, } \\
\text { rain, snow, temperature drop }\end{array}$ & $\begin{array}{l}\text { Can affect any region } \\
\text { Disadvantage for rescue missions }\end{array}$ \\
\hline Human resources & \multicolumn{2}{|l|}{$\begin{array}{l}\text { Lack of trained staff, unpreparedness } \\
\text { Lack of emergency response teams }\end{array}$} \\
\hline Technical problems & \multicolumn{2}{|l|}{ Equipment failure, power outage } \\
\hline
\end{tabular}

Risk management is based on the monitoring of potentially hazardous areas, and restricting access when for example toxic gas emissions reach dangerous levels. Unfortunately, areas at risk quite often lack the necessary funding to install permanent monitoring equipment (Williams-Jones and Rymer 2000). Table 7.4 lists the major factors that can determine success or failure in crisis communication and emergency management.
Case Study 7.6: Japanese JigokuHellish Experience

In the centre of Beppu City on the Japanese island of Kyushu ten small geothermal parks are located. Thousands of tourists visit these parks known as jigoku, which means 'hell' in Japanese, on a daily basis, with many tour groups arriving by bus. There are a variety of geothermal features, 
including a small turquoise crater lake fed by a permanent geyser (Umi Jigoku or Sea Hell), a steaming red pond known as Blood Hell (Chinoike Jigoku), the Priest Hell with bubbling mud ponds (Onishi Bozo Jigoku), the White Hell ponds (Shiraike Jigoku), and others, all of which are popular tourist sites. For the safety of visitors, the boiling lakes are fenced off and warning signs are located at all hazardous features (Fig. 7.4). Public announcements update visitors on important issues of the individual sites and friendly staff members are always around talking to visitors and guiding them from one geothermal feature to another (e.g. Kamado Jigoku). Safety is rarely an issue as Japanese regulations are very strict. Seismic activity and pressure in the underlying hydrothermal system are constantly monitored due to their location in the volcanic dome complex of Mt Tsurumi, which is classed as an active volcano. Also, hazard communication in Japan has over the past decade been extended to include several languages based on increasing number of foreign tourists. Other 'hellish' locations in Japan include Jigokudani near Noboribetsu on the island Hokkaido and the Unzen Jigoku near Shimabara (Kyushu).
Reaching people in an emergency to rescue them or guide them to a safe area depends on access to the affected site and transport options for evacuation. While a crisis is in progress, weather changes can hinder rescue efforts or make them impossible. For example, during the hydrothermal eruption of Mt Ontake (Japan 2014) rescue workers and Self Defence Force helicopters were carrying injured people to safety, but were battling adverse weather conditions as well as communication problems when trying to locate missing people. This disaster was made worse by not recording visitor numbers as should be done at all active volcanic and hydrothermal areas, although this is difficult logistically.

Further challenges to hazard communication, apart from the already mentioned lack of monitoring facilities at remote or underfunded destinations, include visitors blatantly ignoring warning signs and safety announcements. The co-operation of key stakeholders (e.g. scientists, authorities, tourist organisations) also remains difficult and can result in the lack of sufficient and effective emergency management strategies. Paired with procrastination this can delay the required decision making processes, and the timing of when to warn the public of an imminent danger. This is especially if the crisis situation is exacerbated by unfavourable factors including remoteness, large crowds, an ensuing panic or the threat of bad weather together with low visibility and hostile temperatures.

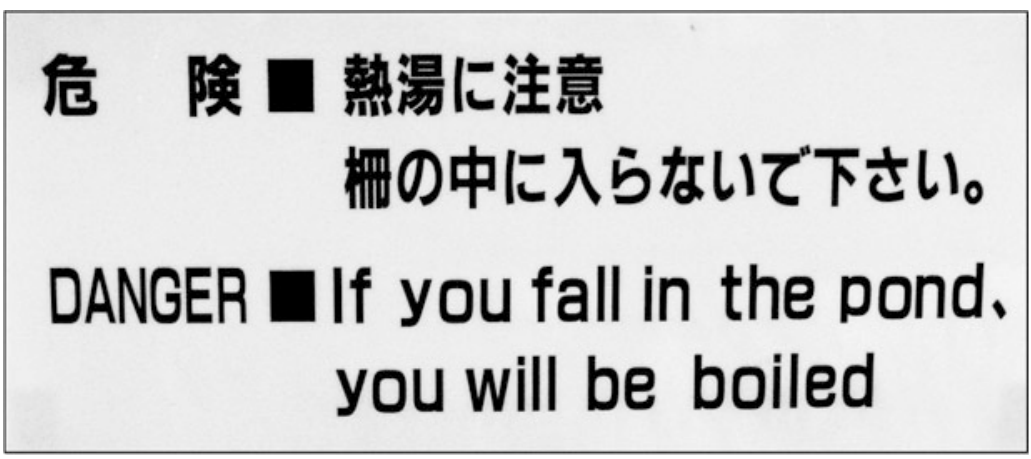

Fig. 7.4 Warning sign in two languages at a boiling pond at one of Beppu's Jigoku. Photo Patricia Erfurt-Cooper 


\subsection{How Are Hazards and Risks in Hydrothermal Areas Communicated to the Public?}

Advising the public of an imminent crisis is generally the responsibility of a local authority, based on the information supplied from scientists monitoring an active area (McGuire et al. 2009), or casual observation. The capacity to communicate safety advice in case of a developing crisis situation depends on a range of factors. Above all the time frame is critical; the sudden onset of a hazardous situation can translate into life-threatening injuries.

Communication of hazards and risks can take place in several ways (Table 7.5). Prior to visiting, people interested in active hydrothermal or volcanic areas certainly have the opportunity to secure information about their chosen destination. While literature about many active environments is available and can be researched at libraries, the most effective way to access up-to-date information is to use reliable online sources for individual destinations (Case Study 7.7) and to check for current conditions and alert levels.

\section{Case Study 7.7: New Zealand}

The Waimangu Volcanic Valley is promoted on the internet as "amazing thermal features combined with lovely bush walks" with "hot springs, steaming lakes and colourful mineral deposits" (Waimangu Volcanic Valley 2015). Not promoted is advice on safety and instructions for emergencies. The "All you need to know" section offers "General information" about guided and self-guided tours and refers to "Guide sheets" in nearly a dozen languages. A brochure covering the area describes Waimangu Valley as "the world's youngest geothermal ecosystem, home to many geothermal features of worldwide importance" refers briefly to sustainable management practices including "safe access to the best viewing points". Information related to potential hazards is not always communicated on websites or brochures. However, after contacting the management at Waimangu it was clarified that safety is a very serious issue with strategies in place for all possible events. Great emphasis is placed on

Table 7.5 Availability of information about hydrothermal (and volcanic) hazards before, during and after visiting

\begin{tabular}{|c|c|c|c|}
\hline Communication channels and their application & Before & During & After \\
\hline Internet sites of destination (e.g. regular updates, alert levels, webcams) & $\mathrm{x}$ & & $\mathrm{x}$ \\
\hline Literature (earth science books and journals, guides books, research papers) & $\mathrm{x}$ & & $\mathrm{x}$ \\
\hline Brochures, fact sheets (park management, tourist offices) & $\mathrm{x}$ & $\mathrm{x}$ & $\mathrm{x}$ \\
\hline Maps, hazard maps with safety instructions & $\mathrm{x}$ & $\mathrm{x}$ & \\
\hline Visitor centres, interpretive centres, science museums & $\mathrm{x}$ & $\mathrm{x}$ & \\
\hline Videos (visitor information, safety advice) & $\mathrm{x}$ & & \\
\hline Documentaries (related to natural crises) & $\mathrm{x}$ & & $\mathrm{x}$ \\
\hline Rangers, tour guides & $\mathrm{x}$ & $\mathrm{x}$ & \\
\hline Social media (fb, twitter, trip advisor) real time updates & $\mathrm{x}$ & $\mathrm{x}$ & $\mathrm{x}$ \\
\hline General media (TV, radio) & $\mathrm{x}$ & & $\mathrm{x}$ \\
\hline Public address systems where installed & & $\mathrm{x}$ & \\
\hline Smart phone apps (if any have been developed) & $\mathrm{x}$ & $\mathrm{x}$ & $\mathrm{x}$ \\
\hline Subscription to text messages, real time updates & & $\mathrm{x}$ & \\
\hline
\end{tabular}


trained staff and all visitors are briefed on arrival at Waimangu to stay safe. Some of the guidelines include staying on the paths at all times and following the directional signs. Written interpretations given to visitors contain further safety messages (pers. email communication with H. James CEO Waimangu). Based on further personal experience from previous visits of geothermal destinations in New Zealand staff at visitor centres and rangers/guides are available to advise on safety and potential dangers and are trained to respond to emergencies.

To communicate potential hazards, some National Parks show visitors introductory videos, hand out brochures, explain safety procedures and advise to strictly obey warning signs. The Hawaii Volcanoes National Park shows informational videos about safe conduct near active features prior to entering the Park to warn people in advance about the various hazards they can encounter. These measures cannot be enforced however, with some visitors to hazardous areas choosing to ignore them. Nevertheless, effective hazard communication is possible; an example is to be found at Mt Aso (Kyushu, Japan), where during visits to the summit public announcements in four different languages constantly update tourists about the level of toxic gas emissions from the crater and whether this poses a risk for visitors on the viewing platform and the surrounding walkways. Evacuation of the area is carried out immediately if the wind direction changes and the situation becomes hazardous for visiting tourists.

Another positive example is found in the Yellowstone National Park, USA, where the emphasis is firmly on public safety to avoid accidents and injuries from hydrothermal features, which have led to fatalities in the past (Case Study 7.8).

\section{Case Study 7.8: Yellowstone-10,000 geothermal Features and 3 Million annual Visitors}

Yellowstone National Park's chief safety officer says that they "try to educate people starting when they come through the gate" and that it is important for parents to keep a close eye on their children when visiting thermal areas. Prior to visiting the Yellowstone website informs people that "wild animals are not the only dangerous threat in Yellowstone", and that there have been a significant number of "deaths and injuries from geysers and geothermal water" over time. While the geothermal features are known to be hazardous, park management is concerned that visitors and even employees are not aware or ignorant of the potential risks when leaving designated walkways (Yellowstone 2014). According to Whittlesey (2014) there have been 19 confirmed human fatalities in Yellowstone's history as a national park from falling into thermal features including children, adults and even people working in the park. Safety managers at Yellowstone also think that incidents of injuries are higher than reported, because people cannot resist testing the water temperature by putting in their fingers or toes and suffer thermal burns. Warnings related to the dangers of geothermal hazards are clearly communicated on Yellowstone's website and are a good example of informing the public ahead of visiting. Throughout the geothermal areas there are warning signs and rangers are trying their best to keep unwary tourists from endangering themselves (Yellowstone 2014).

\section{Case Study 7.9}

The Waikato Regional Council (New Zealand) monitors geothermal sites and develops specific hazard maps for the Waikato region. For visitors to geothermal 
areas the Waikato Council offers some guidelines on their website about potential hazards and how to avoid them:

- Always check the temperature of the water before putting any part of your body in it. Take care not to fall in the water unless you are sure the temperature is safe.

- Keep your head above the water when bathing in geothermal pools. If you have severe flu-like symptoms within a week after visiting a hot pool, see a doctor immediately to rule out amoebic meningitis.

- Don't drink geothermal water in case it contains the toxic minerals arsenic and mercury.

- Be wary of eating trout caught in geothermal streams and lakes, as these fish may contain high levels of mercury.

- Keep a safe distance away from boiling mud pools, geysers and other areas which may suddenly erupt. Remember, a safe distance may be greater than you think, due to the unpredictable size and frequency of these geothermal features (Waikato Regional Council 2014).

Nevertheless, every country has their own methods and legislations how to deal with complex health and safety tasks emerging during crisis situations in relation to hydrothermal hazards. Based on the type of hazard, appropriate crisis management should include strategies for any level of emergency, including preparations for the evacuation of tourists and host communities if necessary. Hence, courtesy of the advanced media coverage we have come to rely on, hazard and crisis communication has far more opportunities to reach the public than even only one or two decades ago. And an abundance of information is available for those who are willing to do some research before embarking on a trip into a potentially hazardous area. However, the above listed methods of hazard communication are not always taken advantage of and they may not all be available for a particular site or destination.

\section{Hazard and Crisis Communication}

\subsection{Alerting the Public- Communicating Warnings}

As mentioned above, the communication of hazards is legally at the discretion of the official management in charge of public safety. Depending on the hydrothermal activity level, appropriate signage and fencing are essential to warn and protect the public under normal conditions. During a crisis situation accurate and up-to-date information about an imminent danger is one of the key elements of effective communication. Difficulties in translating data from monitoring scientists into relevant facts followed by an appropriate course of action can however affect the successful management of an emerging crisis situation (Jolly and De La Cruz 2015; Gregg et al. 2015; McGuire et al. 2009).

In the build-up to a crisis warnings are disseminated through local media outlets (TV, radio, newspaper, website updates). Prior to and during a crisis emergency advice and directions can be communicated through rangers and tour guides, assisted by hazard maps and fact sheets. To communicate alert levels in real time colour coded warning lights and public announcement systems are suitable methods to reach tourists in large or remote areas with volcanic and hydrothermal activity. Finally, depending on the actual area, rescue workers and emergency personnel on site should be available to assist the public. Mobile phone message subscriptions and digital Apps are increasingly playing a part in reaching people prior and during emergencies, which shows that text messages carrying information about geo-hazards can be communicated to registered users in real time. To avoid misinterpretations Ghosh et al. (2012) note that " $a$ generalized system that could be deployed for any geo-hazard across any region" should be 
developed. However, as many hydrothermal tourist destinations are located near active volcanoes, alert level systems as described in detail by several scientists (Fearnley et al. 2012; Gregg et al. 2015; Jolly and De La Cruz 2015; McNutt 2015; Williams-Jones and Rymer 2015) could possibly be modified and implemented at hydrothermal sites where required.

\subsection{The Main Stakeholders and Their Responsibilities}

As with volcanic environments planning for hydrothermal areas includes consultation and discussion between all stakeholders (Gregg et al. 2015). To communicate potential hazards to stakeholders (Connor et al. 2015), prior education through ranger talks, videos, brochures, and the internet can prepare visitors for the need of hazard and crisis communication in hydrothermal areas by raising their awareness. At the first signs of an emerging crisis situation, effective and reliable communication must be established between the stakeholders to develop a strong working relationship to cope with the crisis as it unfolds. While the most important stakeholder group in terms of tourism are the visiting tourists, three main stakeholder groups are identified by McGuire et al. (2009): the monitoring scientists, the emergency managers, and the media. However, local authorities and resident communities also constitute important stakeholder groups at hydrothermal tourist destinations. Heath et al. (2009) acknowledge that stakeholder partnerships, which include the public are the key to effective hazard and crisis communication.

Monitoring scientists are responsible for detecting early warning signs and assessing activity levels to provide information and guidance in an emergency situation. The role of emergency management committees is to determine an appropriate response strategy based on such scientific data, to develop hazard maps and risk management strategies and to take a pro-active role in educating the public about the nature of the emergency situation (Gregg et al. 2015; McGuire et al. 2009). To prevent misunderstandings that may result in misinterpretation and delay in the decision making process in a crisis situation, it is critical that the communication between scientists and all other stakeholders is clear and unambiguous (Doyle et al. 2014). The media then should focus only on information, which is specific to the situation and present warning messages in a form that is clearly understood by everybody. To convey information effectively all irrelevant data should be avoided in media releases as it can confuse the public (Leonard et al. 2008; McGuire et al. 2009; Sorensen 2000). Warning messages should be consistent and designed to include those with poor literacy, language problems or disabilities effectively in the information stream. Pictures, drawings and video footage are useful ways to communicate with international visitors, and at the same time avoid confusion with terminology (Erfurt-Cooper and Cooper 2010, Erfurt-Cooper 2014; McGuire et al. 2009).

Scientists sometimes may be reluctant to communicate scientific information to other stakeholders based on their experience of misinterpretation or selective use of their data (Boykoff 2008). While there have been advances in the field of communicating geo-hazards, much needs to be done to improve the engagement between all stakeholders (monitoring scientists, politicians, government agencies, emergency managers, representatives of the media, and the public) to ensure seamless co-operation and effective communication (Liverman 2010; McGuire et al. 2009).

\section{Hazard Management}

\subsection{Why Are People Reluctant to Respond to Warnings?}

An emergency situation in areas of hydrothermal activity can be caused by a natural event and affect many people, but very little can be done to prevent it from happening. Disaster preparedness can offset some of the hazards in this situation, but not all. However, another type of emergency is caused by humans who are frequently injured 
as a result of being careless, and this situation can be avoided. In the Yellowstone National Park for example accidents and injuries are nearly always due to visitors being irresponsible in thermal areas with a number of reasons for injuries identified by Whittlesey (2014):

- Walking in off-limit areas

- Walking in darkness

- Losing balance

- Being intoxicated

- Being distracted

- Over-confidence

- Ignoring warnings

- Careless running

Whittlesey (2014) rightly points out that " $a$ balance is needed between adequate warnings and basic responsibility from the visitor". Individuals, who choose not to respond to hazard warnings or worse, in a crisis situation may not do so because (a) they are unfamiliar with the hazard, or (b) they think they can avoid the hazard altogether, while (c) others believe it could be a false alarm, and (d) if not, somebody will come to their rescue.

One of the key factors influencing the decisions of individual people in these situations is their personal risk perception, which can range from being overcautious to ignoring a potential risk, or to the complete denial of any danger. In addition, apart from a possible uncertainty about the risk, a negative attitude towards authorities could be another reason for ignoring safety advice. Furthermore, tourists frequently overestimate their personal ability to cope with dangerous situations while at the same time underestimating the actual risk and their own vulnerability. Here it would be advisable to provide all visitors of active hydrothermal environments with detailed safety guidelines, which they should refer to before and during their visit.

Virtual reality is in this day and age a valuable tool for travel planning and the internet offers many sources to assist detailed research of planned destinations including webcams, videos and computer simulations. While cyber visits to extreme landscapes and hazardous areas may lack the actual risk, they can help visitors and host communities to understand the potential difficulties as well as the risks that can be encountered in the real world (Erfurt-Cooper and Cooper 2009). However, despite the advent of real-time internet resources, the task of hazard and risk management in volcanic and hydrothermal environments remains extremely challenging, as varying degrees of potential danger from hydrothermal activity as well as correlated volcanic and seismic events generate different types of hazards (Erfurt-Cooper and Cooper 2009).

\subsection{Why Are Authorities Reluctant to Announce Evacuations?}

Not being aware of the potential hazards in an active area prior to visiting could mean the difference between safety and injury. So, if this is true, and if maintaining a high level of communication means that public warnings are the responsibility of the authorities (McGuire et al. 2009), why are some authorities reluctant to announce evacuations? As suggested by Francis and Oppenheimer (2004), all details of risk management strategies need to be planned and in place, including successful evacuation, transport and medical care. However, this may not be common knowledge, as for the tourism industry disasters are generally bad for business. Thus, if warnings are given too early, they might be ignored by the public, or in the case of repeated warnings without anything happening they may also be ignored (the cry wolf syndrome). Nevertheless, to avoid endangering the public, good management strategies are required to assist with hazard communication, crisis planning and to prevent emergency situations getting out of hand.

When it comes to the drastic measure of calling an evacuation, authorities may be reluctant to do so for several reasons. Uncertainty about the actual risk combined with a lack of scientific knowledge and experience on the part of some stakeholders can make the decision making process difficult. In the case of insufficiently trained staff and/or in the absence of 
monitoring facilities the reliable assessment of imminent danger can be impossible. Emergency managers and response teams can also have their tasks complicated by unfavourable logistics based on remote terrain, weather, lack of time and/or inadequate strategies. When local authorities are incapable of dealing with emergencies, external rescue response teams may have to be called in to assist, which again may delay the decision to evacuate. Occasionally political disagreements such as cross border problems can come into play, presenting another reason for making hazard communication and crisis management including successful evacuation unworkable.

To generate effective and accurate communication before, during and after a crisis therefore remains a challenge, because it depends on numerous variables. More to the point, hazard communication is mainly focussed on volcanic environments with hydrothermal areas in need of higher levels of targeted research to improve hazard communication and crisis management. If reliable information is not available or is only partial, it becomes obvious how delays in effective crisis response can occur.

\section{Conclusion}

Health and safety issues play a major role in the tourism industry based on hydrothermal and volcanic resources (Erfurt-Cooper 2008, 2010, 2014). While it is essential to prevent injuries to tourists the management of effectively communicating hydrothermal hazards remains problematic. Precursory signs indicating a dangerous natural event are still not completely understood and the communication of imminent danger is frequently unachievable. As a consequence, serious thought needs to be given to improvements in the communication of risk factors and potential dangers from the proximity of active hydrothermal surface features, including extreme hot springs and geysers, as well as areas affected by hydrothermal alteration resulting in unstable ground properties.
To reduce the risk factor, it is essential to raise visitor awareness about any potential hazards in hydrothermal tourist areas and put management strategies for emergencies in place. Advice for visitors of active hydrothermal environments should include guidance and recommendations how to cope with extreme events in difficult situations (Erfurt-Cooper 2008, 2010, 2014). To improve the safety standards in these areas, strategic guidelines for safe conduct should cover all active hydrothermal areas and must be designed to be understood by every visitor. In seeking to achieve this ideal state, one of the questions arising is whether visitors to these areas seek enough information from available sources prior to their journey (Appendices 1 and 2). However, the overall hazard, risk and crisis communication process for active hydrothermal environments is a problem, which frequently is insufficiently addressed at tourist destinations. While some areas have staken steps to educate visitors about potential dangers the moment they arrive (Yellowstone 2014), other areas do not offer adequate safety information. Here virtual reality can be a valuable tool for travel planning with the internet offering numerous comparable sources (e.g. webcams, videos and computer simulations) to research planned destinations.

This chapter has presented an overview of the most common hazards or risk factors in hydrothermal areas with brief case studies to exemplify different scenarios. To highlight the challenges of risk management and the need for effective communication a number of locations were discussed for their site specific hazards and their potential risks. The literature reviewed for this chapter indicates a scarcity of research for hazard communication in hydrothermal areas and hence information related to this topic remains limited. In conclusion, it is recommended that more studies are undertaken to contribute to the safety of visitors in these environments and that more destination websites include safety advice relating to their hydrothermal tourist attractions. 


\section{Appendix 1}

Example of safety advice-extract from USGS factsheet (USGS ${ }^{3}$ 2007).

U.S. Geological Survey and the U.S. Forest Service-Our Volcanic Public Lands.

Boiling Water at Hot Creek-The Dangerous and Dynamic Thermal Springs in California's Long Valley Caldera.
This Fact Sheet and any updates to it are available online at http://pubs.usgs.gov/fs/2007/ 3045 .

\section{VISITING HOT CREEK SAFELY}

Visiting Hot Creek can be an enjoyable and rewarding experience, but you should be aware of the dangers and take them seriously. Know the hazards-boiling or scalding water, steam vents, unstable ground and boulders, hot ground or mud, swiftly flowing water, a stream with unpredictable currents, and water unfit for human consumption.

\section{Follow these tips for your safety:}

- Keep a clear head and be observant-conditions can change quickly.

- Keep careful watch on children and pets (always keep pets on a leash).

- Follow directions and warnings on signs.

\section{- Don't cross over fences or} barriers, and stay on walkways.

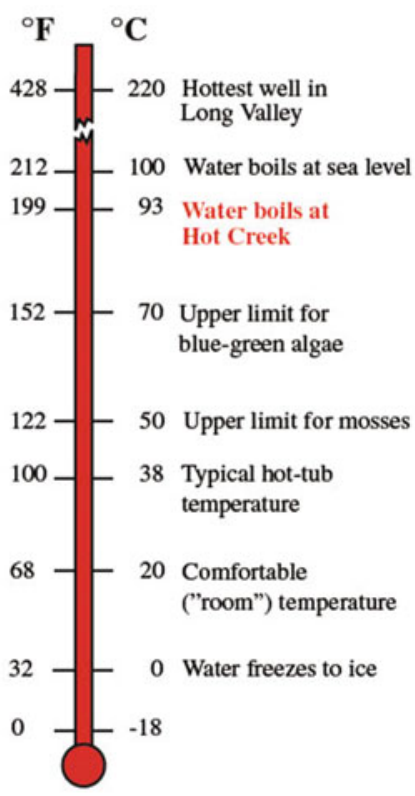

How to get there:

The Hot Creek Geologic Site is located northeast of the Mammoth-Yosemite Airport and is accessed from U.S. Highway 395 by the Hot Creek Hatchery Road. 


\section{Appendix 2}

\section{HAZARDOUS EVENTS AT YELLOWSTONE}

\begin{abstract}
Scientists evaluate natural-hazard levels by combining their knowledge of the frequency and the severity of hazardous events. In the Yellowstone region, damaging hydrothermal explosions and earthquakes can occur several times a century. Lava flows and small volcanic eruptions occur only rarely - none in the past 70,000 years. Massive caldera-forming eruptions, though the most potentially devastating of Yellowstone's hazards, are extremely rare-only three have occurred in the past several million years. U.S. Geological Survey, University of Utah, and National Park Service scientists with the Yellowstone Volcano Observatory (YVO) see no evidence that another such cataclysmic eruption will occur at Yellowstone in the foreseeable future. Recurrence intervals of these events are neither regular nor predictable.
\end{abstract}

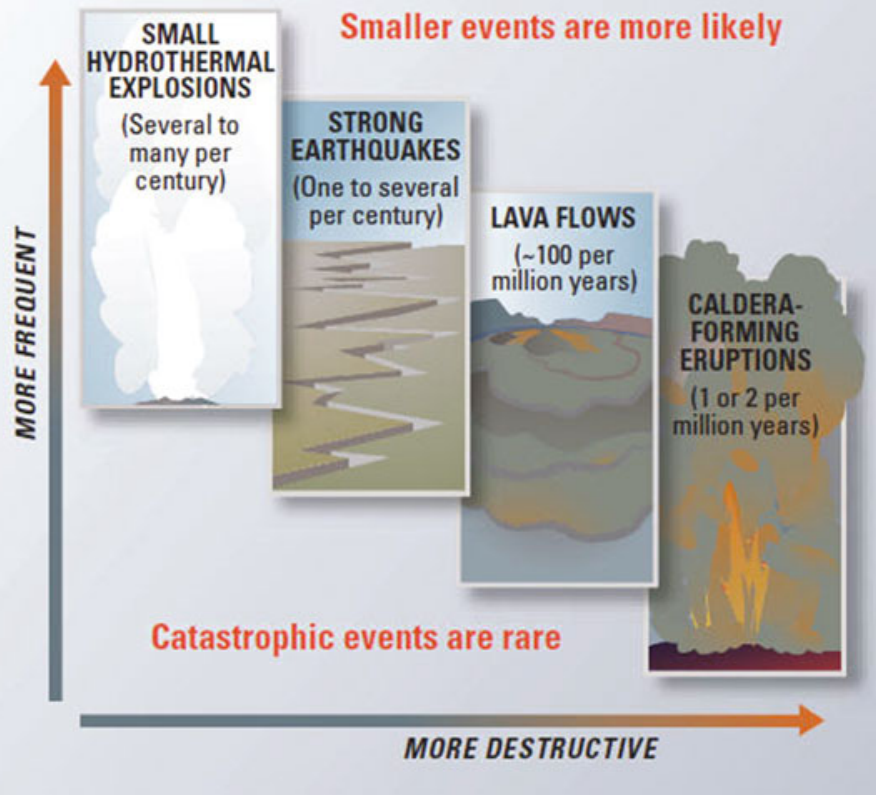

\section{How Dangerous Is Yellowstone?}

None of the events described above-cataclysmic caldera-forming eruptions, lava flows, large earthquakes, or major hydrothermal explosionsare common in Yellowstone. Although visitors to Yellowstone National Park may never experience them, some hazardous events are certain to occur in the future. Fortunately, systematic monitoring of Yellowstone's active volcanic and hydrothermal systems, including monitoring of earthquakes and ground deformation, is now carried out routinely by YVO scientists.

This monitoring will allow YVO to alert the public well in advance of any future volcanic changes in the patterns of ongoing seismicity or other indicators of possible geologic unrest are quickly reported to officials responsible for public safety in the National Park Service and other agencies.

Through continuous monitoring and research, YVO is greatly improving understanding of
Yellowstone's volcanic, earthquake, and hydrothermal hazards. The work of USGS scientists with YVO is only part of the USGS Volcano Hazards Program's ongoing efforts to protect people's lives and property in all of the volcanic regions of the United States, including California, Hawaii, Alaska, and the Pacific Northwest (Lowenstern et al. 2005).

\section{References}

Aspinall W, Blong R (2015) Volcanic risk assessment. In: Sigurdsson $\mathrm{H}$ (ed) Encyclopedia of volcanoes, 2nd edn. Elsevier-Academic Press, Amsterdam, pp 1215-1231

Barclay J, Haynes K, Houghton B, Johnston D (2015) Social processes and volcanic risk reduction. In: Sigurdsson $\mathrm{H}$ (ed) Encyclopedia of volcanoes, 2nd edn. ElsevierAcademic Press, Amsterdam, pp 1203-1214

Barnett ND, Kaplan AM, Hopkin RJ, Saubolle MA, Rudinsky MF (1996) Primary amoebic meningoencephalitis with Naegleria fowleri: clinical review. Ped Neuro 15:230-234 
BBC News (2010) Boy dies after New Zealand geothermal pool fall. 30 December 2010. www.bbc.co.uk/ news/world-asia-pacific-12091845. Accessed 10 Aug 2016

Boykoff M (2008) Media and scientific communication: a case of climate change. In: Liverman DGE, Pereira CP, Marker B (eds) Communicating environmental geoscience, vol 305. Geological Society of London Special Publication, pp 11-18

Bratton A, Smith B, McKinley J, Lilley K (2013) Expanding the geoconservation toolbox: integrated hazard management at dynamic geoheritage sites. Geoheritage 5:173-183

Connor C, Bebbington M, Marzocchi W (2015) Probabilistic volcanic hazard assessment. In: Sigurdsson $\mathrm{H}$ et al (ed) Encyclopedia of volcanoes, 2nd edn. Elsevier-Academic Press, Amsterdam, pp 897-910

De La Cruz-Reyna S, Meli RP, Quaas RW (2000) Volcanic crises management. In: Sigurdsson $\mathrm{H}$ et al (eds) Encyclopedia of volcanoes. Elsevier-Academic Press, Amsterdam

Dengler L (2005) The role of education in the National Tsunami Hazard Mitigation Program. Nat Hazards 35:141-153

Doyle EEH, McClure J, Johnston DM, Paton D (2014) Communicating likelihoods and probabilities in forecasts of volcanic eruptions. J Volcanol Geoth Res 272:1-15

Erfurt-Cooper P (2008) Geotourism: active geothermal and volcanic environments as tourist destinations, presented to The Inaugural Global Geotourism Conference. Perth, Australia, 17-20 August

Erfurt-Cooper P (2010) Introduction to volcano and geothermal tourism. In: Erfurt-Cooper P, Cooper M (eds) Volcano and geothermal tourism: sustainable geo-resources for leisure and recreation. Earthscan, London

Erfurt-Cooper P (2012) An assessment of the role of natural hot and mineral springs in health, wellness and recreational tourism. Dissertation, James Cook University

Erfurt-Cooper P (ed) (2014) Volcanic tourist destinations. Geoheritage, Geoparks and Geotourism Series. Springer, Berlin

Erfurt-Cooper P, Cooper M (2009) Health and wellness tourism: spas and hot springs. Channel View Publications, Bristol, UK

Erfurt-Cooper P, Cooper M (2010) Volcano and geothermal tourism: sustainable geo-resources for leisure and recreation. Earthscan, London

Fearnley CJ, McGuire WJ, Davies G, Twigg J (2012) Standardisation of the USGS volcano alert level system (VALS): analysis and ramifications. Bull Volcanol 74:2023-2036

Francis P, Oppenheimer C (2004) Volcanoes, 2nd edn. Oxford University Press, Oxford

Gregg CE, Houghton B, Ewert JW (2015) Volcano warning systems. In: Sigurdsson H (ed) Encyclopedia of volcanoes, 2nd edn. Elsevier-Academic Press, pp 1173-1185

Ghosh JK, Bhattacharya D, Samadhiya NK, Boccardo P (2012) A generalized geo-hazard warning system. Nat Hazards 64:1273-1289
Haase KM et al. (2009) Fluid compositions and mineralogy of precipitates from Mid Atlantic Ridge hydrothermal vents at $4^{\circ} 48^{\prime} \mathrm{S}$. Pangaea

Hansell AL, Horwell CJ, Oppenheimer C (2006) The health hazards of volcanoes and geothermal areas. Occup Environ Med 63:149-156

Heasler HP, Jaworowski C, Foley D (2009) Geothermal systems and monitoring hydrothermal features. In: Young R, Norby L (eds) Geological monitoring: Boulder, Colorado. Geological Society of America, pp 105-140

Heath RL, Jaesub L, Lan N (2009) Crisis and risk approaches to emergency management planning and communication: the role of similarity and sensitivity. J Pub Relat Res 2(2):123-141

Heggie TW, Heggie TM, Heggie TJ (2010) Death by volcanic laze. In: Erfurt-Cooper P, Cooper M (eds) Volcano and geothermal tourism: sustainable geo-resources for leisure and recreation. Earthscan, London

Hochstein MP, Browne PRL (2000) Surface manifestations of geothermal systems with volcanic heat sources. In Sigurdsson H et al (eds) Encyclopedia of volcanoes. Elsevier-Academic Press, Amsterdam

Jolly G, De La Cruz S (2015) Volcanic crisis management. In: Sigurdsson $\mathrm{H}$ et al (ed) Encyclopedia of volcanoes, 2nd edn. Elsevier-Academic Press, Amsterdam, pp 1187-1202

Keary P (1996) The new Penguin dictionary of geology. Penguin Books, London

Leonard GS, Johnston DM, Paton D, Christianson A, Becker J, Keys H (2008) Developing effective warning systems: ongoing research at Ruapehu volcano, New Zealand. J Volcanol Geoth Res 172:199-215

Liverman D (2010) Communicating geological hazards: educating, training and assisting geoscientists in communication skills. In: Beer T (ed) Geophysical hazards-minimizing risk, maximizing awareness. International Year of Planet Earth. Springer, The Netherlands, pp 41-55

Lowenstern JB, Christiansen RL, Smith RB, Morgan LA, Heasler H (2005) Steam explosions, earthquakes, and volcanic eruptions-what's in Yellowstone's future? U.S. Geological Survey. http://pubs.usgs.gov/fs/2005/ 3024/. Accessed 10 Aug 2016

McGuire WJ, Solana MC, Kilburn CRJ, Sanderson D (2009) Improving communication during volcanic crises on small, vulnerable islands. J Volcanol Geoth Res. doi:10.1016/j.jvolgeores.2009.02.019

McNutt S (2015) Eruption response and mitigation. In: Sigurdsson $\mathrm{H}$ et al (ed) Encyclopedia of volcanoes, 2nd edn. Elsevier-Academic Press, Amsterdam, pp 1069-1070

NZ Herald (2013) Hot pool death: coroner satisfied with council's actions. www.nzherald.co.nz/nz/news/ article.cfm?c_id=1\&objectid=10862848. Accessed 10 Aug 2016

Paton D, Millar M, Johnston DM (2001) Community resilience to volcanic hazard consequences. Nat Hazards 24:157-169 
Roscoe R (2010) Geothermal parks in New Zealand. In: Erfurt-Cooper P, Cooper M (eds) Volcano and geothermal tourism: sustainable geo-resources for leisure and recreation. Earthscan, London

Sorensen JH (2000) Hazard warning systems: review of 20 years of progress. Nat Hazards Rev 1(2):119-125

Steelman TA, McCaffrey S (2013) Best practices in risk and crisis communication: implications for natural hazards management. Nat Hazards 65:683-705

Think Geoenergy (2015) Geothermal plants among top tourist attractions in Iceland. http://www.thinkgeoenergy.com/geothermal-plants-among-top-tourist-at tractions-in-iceland/. Accessed 10 August 2016

TVNZ (2012) Inquest into boy's death in Rotorua mud pool. 20 Dec 2012. http://tvnz.co.nz/national-news/ inquest-into-boy-s-death-in-rotorua-mud-pool-5299381. Accessed 20 Jan 2015

UNISDR (2014) Terminology on DRR. The United Nations Office for Disaster Risk Reduction. www. unisdr.org/we/inform/terminology. Accessed 10 Aug 2016

UNISIDR (2016) Hyogo framework for action (HFA)building the resilience of nations and communities to disasters. The United Nations Office for Disaster Risk Reduction. www.unisdr.org/we/coordinate/hfa. Accessed 6 Aug 2016

USGS $^{3}$ (2007) Boiling water at hot creek-the dangerous and dynamic thermal springs in California's Long Valley Caldera. http://pubs.usgs.gov/fs/2007/3045/. Accessed 10 Aug 2016

USGS $^{1}$ (2014) Volcanic gases and their effects. Volcanic gases can be harmful to health, vegetation and infrastructure. Volcano Hazards Program. http:// volcanoes.usgs.gov/hazards/gas/. Accessed 10 Aug 2016

USGS $^{2}$ (2014) Hydrothermal explosions. Yellowstone volcano observatory. http://volcanoes.usgs.gov/ volcanoes/yellowstone/yellowstone_hazard_43.html. Accessed 10 Aug 2016

Waikato Regional Council (2014) Geothermal activity Regional hazards and emergency management. www. waikatoregion.govt.nz/Services/Regional-services/Regional-hazards-and-emergency-management/Geothermal-activity/. Accessed 10 August 2016

Waimangu Volcanic Valley (2015) Rotorua, New Zealand-amazing geothermal activity. www.waimangu. co.nz. Accessed 10 Aug 2016

Whittlesey LH (2014) Death in Yellowstone: accidents and foolhardiness in the First National Park, 2nd edn. Amazon Digital Services, Inc., Roberts Rinehard

Williams D, Olaniran BA (1998) Expanding the crisis planning function: introducing elements of risk communication to crisis communication practice. Public Relat Rev 24(3):387-400

Williams-Jones G, Rymer H (2000) Hazards of volcanic gases. In: Sigurdsson $\mathrm{H}$ et al (ed) Encyclopedia of volcanoes. Elsevier-Academic Press, Amsterdam

Williams-Jones G, Rymer H (2015) Hazards of volcanic gases. In: Sigurdsson H (ed) Encyclopedia of volcanoes, 2nd edn. Elsevier-Academic Press, Amsterdam, pp 985-992

Yellowstone (2014) Geothermal attractions can be dangerous. Deaths and injuries at Yellowstone's geysers and hot springs. www.yellowstonepark.com/2007/01/ cautionary-tale/. Accessed 10 Aug 2016
Open Access This chapter is distributed under the terms of the Creative Commons Attribution 4.0 International License (http://creativecommons.org/licenses/by/4.0/), which permits use, duplication, adaptation, distribution and reproduction in any medium or format, as long as you give appropriate credit to the original author(s) and the source, provide a link to the Creative Commons license and indicate if changes were made.
The images or other third party material in this chapter are included in the work's Creative Commons license, unless indicated otherwise in the credit line; if such material is not included in the work's Creative Commons license and the respective action is not permitted by statutory regulation, users will need to obtain permission from the license holder to duplicate, adapt or reproduce the material. 